\title{
Downregulation of Caspase-2 Expression in Somitic Cells following Coculture with Chicken Notochord
}

\author{
Rezgar Rahbari, ${ }^{1}$ Mohammad Mazani, ${ }^{1}$ \\ Mohammad Ghasem Golmohammadi, ${ }^{2}$ and Mohsen Sagha ${ }^{2}$ \\ ${ }^{1}$ Department of Biochemistry, School of Medicine, Ardabil University of Medical Sciences, Ardabil 56189-53141, Iran \\ ${ }^{2}$ Research Laboratory for Embryology and Stem Cells, Department of Anatomical Sciences and Pathology, School of Medicine, \\ Ardabil University of Medical Sciences, Ardabil 56189-53141, Iran \\ Correspondence should be addressed to Mohsen Sagha; m.sagha@arums.ac.ir
}

Received 17 June 2013; Accepted 9 July 2013

Academic Editors: P. Li and A. A. Minin

Copyright (c) 2013 Rezgar Rahbari et al. This is an open access article distributed under the Creative Commons Attribution License, which permits unrestricted use, distribution, and reproduction in any medium, provided the original work is properly cited.

\begin{abstract}
Somites are spherical aggregations of mesodermal cells located on either sides of neural tube and are differentiated into sclerotome and dermomyotome. Notochord as an axial mesoderm has a major role in somitic cell survival and differentiation in vivo. Despite secreting the survival factors, how to notochord inhibits somitic cells apoptosis remains to be elusive. So, this study was aimed to investigate downregulation of caspase-2 expression in somitic cells upon coculturing with notochord. By using alginate system to encapsulate the isolated notochord in Somite + Notochord group, the embryonic somites were cocultured with the notochord on different days. Concurrently in somite group, the somites were cultured alone. Survival assay with MTT showed that the rate of viability in somitic cells cocultured with notochord increased from $59 \%$ on day 2 to $89.7 \%$ on day 6 but decreased to $38.5 \%$ on day 10 after coculturing. Reverse transcriptase-polymerase chain reaction and spectrophotometry analysis also confirmed these findings and showed low caspase- 2 and high $B c l$-2 expressions and low caspase- 2 enzyme activity in somitic cells cocultured with notochord, respectively. These results clearly show that the notochord enhances survival of somitic cells in vitro through downregulating of caspase-2 expression along with triggering differentiation of somitic cells to Pax-1 expressing mesenchymal cells.
\end{abstract}

\section{Introduction}

The body axis of early embryo is made up of repetitive series of segments called somites that develop from paraxial mesoderm flanking neural tube and notochord. They form epithelial blocks of mesodermal cells budding from the rostral end of bilaterally presomitic mesoderm which originates from primitive streak [1-3]. Upon formation, signals emanating from neighboring tissues promote the newly formed somitic cells differentiation into dorsal dermomyotome and ventral sclerotome. Then, the sclerotomal cells migrate toward the notochord and surround it to form axial skeletons from which the vertebrae and ribs will be shaped. The dermomyotomal cells are also differentiated to dorsomedial epaxial muscle precursor cells forming axial skeleton associated muscles and dorsolateral hypaxial muscle cells which give rise to body wall and limb muscles. The central dermal portion of dermomyotome also develops to the dermis $[2,4]$.
During gastrulation, the notochord, as an axial structure arising from primitive node, functions as an axis to support the early embryo and finally gives rise to intervertebral disc. Several studies indicate that the notochord also stimulates the developing neural tube to generate motoneurons and, hence, sonic hedgehog (Shh) as a signaling molecule secreting from the notochord and, then, floor plate of the neural tube has a key role in motoneuron generation [5-8]. Moreover, it has been shown that the notochord promotes the survival and differentiation of somites into sclerotomal cells and Shh mimics the effects of notochord to diminish cell death in the somitic cells and enhances their viability. On the other hand, ablation of the notochord in chick embryo also activates apoptotic pathway and promotes programmed cell death in somites $[9,10]$.

Apoptosis is a tightly regulated biological event which occurs in embryonic development and has a crucial role in the development of some organs including limb bud and 
cardiovascular system [11, 12]. Signaling molecules including Fas ligand and tumor necrosis factor- $\alpha(\mathrm{TNF} \alpha)$ promote apoptosis via a family of cysteine proteases, called Caspases, which act as upstream initiators (e.g., Caspases-8 and -9) or downstream effectors (e.g., Caspases-3, -6, and -7) that are primarily responsible for the limited proteolysis. In addition, Caspase-2 is also one of the initiator caspases which is activated rapidly in response to extensive apoptotic signals, but its mechanism of activation is not known. It has been reported that Caspase-2 is activated particularly in developing tissues such as neural and retinal tissues and highly expressed in developing somites when embryonic axial organs are ablated [10]. Moreover, Bcl-2, as an antiapoptotic protein inhibits cell death by controlling mitochondrial membrane permeabilization and blocking the release of cytochrome $\mathrm{C}$ from the mitochondria and hence functions as a guard for mitochondrial integrity [13-16].

In vivo study of cellular signaling pathways is more complex. So, coculture systems can be applied as an in vitro strategy for study of different tissue interactions under controlled conditions. We have recently showed that the somites have a neural inducing ability upon coculturing with mouse embryonic stem cells (ESCs) and in association with notochord promote neural patterning of human ESCs and human ESCs-derived neural precursor cells [17-19]. Here, we demonstrate that the somitic cell survival in monolayer culture depends on the presence of notochord and reveals in vitro evidence for antiapoptotic role of notochord on somites through downregulation of caspase-2 expression. Our findings also indicate that the notochord concurrently promotes in vitro somitic cells differentiation into Pax-1 expressing sclerotomal cells which can be used as a cell model for further biological studies.

\section{Materials and Methods}

2.1. Coculturing of the Somites with Notochords. Fertile hen's eggs provided from commercial sources were incubated in humidified condition at $38^{\circ} \mathrm{C}$. Chick embryos at stages $8-$ 10, according to Hamburger and Hamilton's developmental table, were isolated from yolk surface and transferred to L15 medium (Gibco, 41300-021) (Figure 1(a)). After separating embryos from the area opaca, they were transferred to new L15 medium containing dispase (1 mg/mL, Gibco, 17105-041) for 3-5 min in order to loosen the chick embryo tissues. Subsequently, dispase was removed and the embryos were washed with L15 medium supplemented with $5 \%$ fetal bovine serum (FBS, Gibco, 10270). Then, notochord and somites were isolated from embryos under a dissecting microscope and transferred to L15 medium without FBS (Figures 1(b) and $1(\mathrm{c})$ ). Finally, the notochords were encapsulated into alginate beads as previously described [20]. In brief, dissected notochord explants were transferred to $1.2 \%$ alginate solution (Sigma, A7003) in $0.9 \%$ saline solution and then $20 \mu \mathrm{L}$ of the alginate solution containing 15 notochord explants as a single droplet were slowly released into $102 \mathrm{mM} \mathrm{CaCl} \mathrm{Ca}_{2}$ (Sigma, C7902). After $10 \mathrm{~min}$, beads containing notochord explants were washed twice by $0.9 \%$ saline solution followed by washing with DMEM/F12 ${ }^{\text {Glutamax }}$ medium (Gibco, 31331). For coculturing of somites with notochord, 30 somites and 15 encapsulated notochords were transferred into 24-well culture dish coated with $0.1 \%$ gelatin (Sigma, G2500) in DMEM/F12 ${ }^{+ \text {Glutamax }}$ medium supplemented with $10 \%$ FBS, 1\% NEAA, (Gibco, 11140050), 1\% Pen/Strep (Gibco, 15140122), and $1 \mathrm{mM}$ 2-Mercaptoethanol (Sigma, M7522) for 2, 4, 6, and 10 days.

2.2. Survival Assay by MTT. Viability of somitic cells was evaluated by using 3-(4,5-Dimethylthiazol-2-yl)-2,5-diphenyltetrazolium bromide (MTT) test. For this purpose, the somitic cells were washed with PBS after removing the notochord and culture medium. Then, $20 \mu \mathrm{L}$ of MTT solution (Sigma, M2128) were mixed with $180 \mu \mathrm{L}$ medium and added to somitic cells. The cells were incubated for $4 \mathrm{~h}$ at $37^{\circ} \mathrm{C}$ in $\mathrm{CO}_{2}$-incubator. Finally, MTT solution was completely replaced with the same volume $(200 \mu \mathrm{L})$ of DMSO and the somitic cells were shaked at $150 \mathrm{rpm}$ for $10 \mathrm{~min}$, and optical density at $540 \mathrm{~nm}$ was registered by the plate reader.

2.3. Semiquantitative Reverse Transcriptase-PCR. Total RNA was isolated from somitic cells immediately after isolation (on day 0 , as a control group) and the cells cultured with (Som + Not) or without (Som) notochord for 6 days by using Trizol reagent (Gibco, 15596-026) as described by the manufacturer's instructions. Then, $1 \mu \mathrm{g}$ extracted RNA was used for cDNA synthesis and subjected for PCR amplification by 2 -step RT-PCR Kit (Vivantis, RTRPL12). The amounts of total mRNA in the amplification mixtures were made equivalent according to their GAPDH content. Primer sequences, annealing temperature, number of cycles, and the length of amplified products were presented in Table 1. PCR products were electrophoresed in $1.2 \%$ agarose gels containing ethidium bromide and bands were visualized with UV light (Uvidoc, UK). Finally, to analyze semiquantitative expression of different mRNAs, the amount of cDNA was normalized based on the GAPDH mRNA expression using ImageJ software. Gels of three independent repeats were analyzed.

2.4. Spectrophotometry for Caspase-2. Enzyme activity for Caspase-2 was determined by spectrophotometric methods by using Caspase- 2 kit according to the manufacturer's protocol (Biovision, K117-25). The rate of hydrolysis p-nitroanilide from the labeled substrate was measured at $405 \mathrm{~nm}$ at $37^{\circ} \mathrm{C}$ and the results were presented as fold increase for somitic cells in Som and Som + Not groups after 6-day coculture.

2.5. Statistical Analysis. Quantification of MTT assay and spectrophotometry test for Caspase-2 activity was performed based on five and three independent repeats, respectively, and the data normalized with control group on day 0 (upon somite isolation) were presented as a mean percentage or fold increase \pm SEM and analyzed by one-way/two-way ANOVA followed by Tukey's post hoc multiple group comparison test or independent Student's $t$-test. Statistically, a difference between groups was considered as significant if $P<0.05$. 


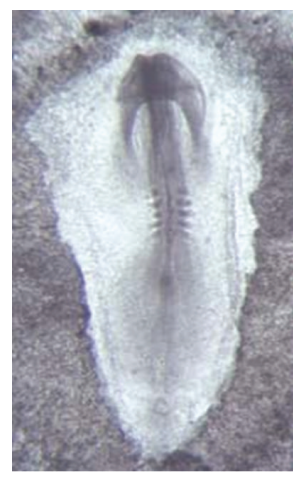

(a)

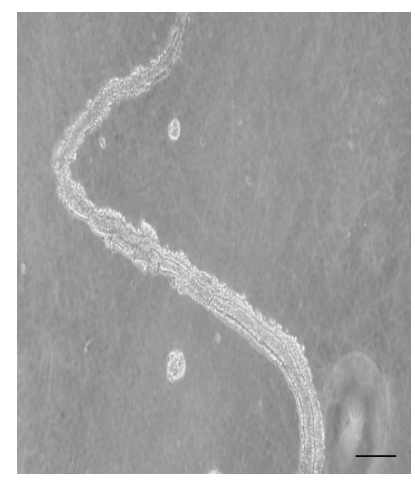

(b)

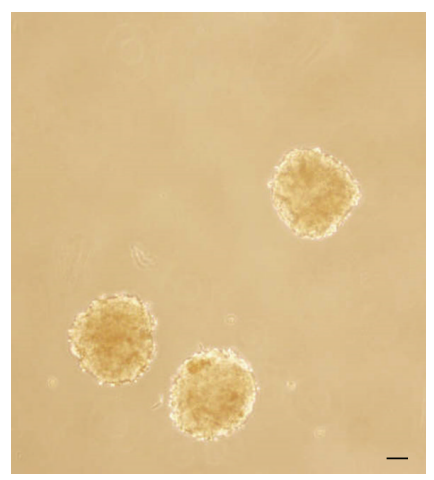

(c)

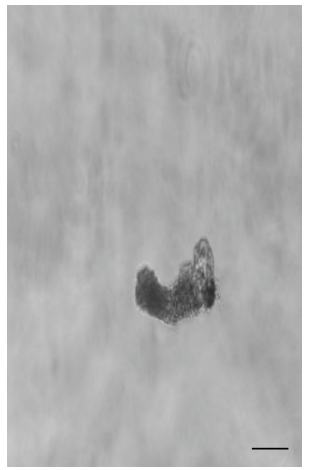

(d)

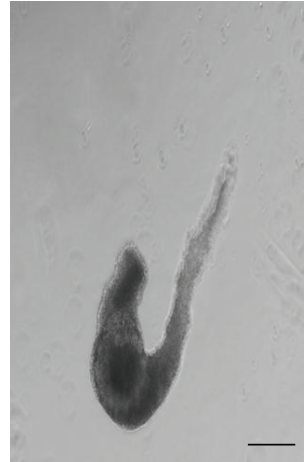

(e)

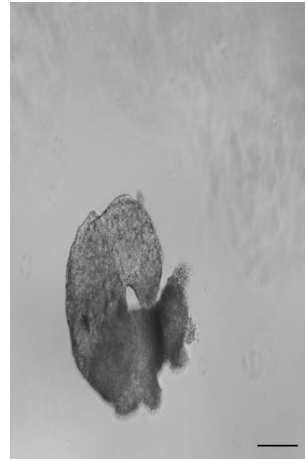

(f)

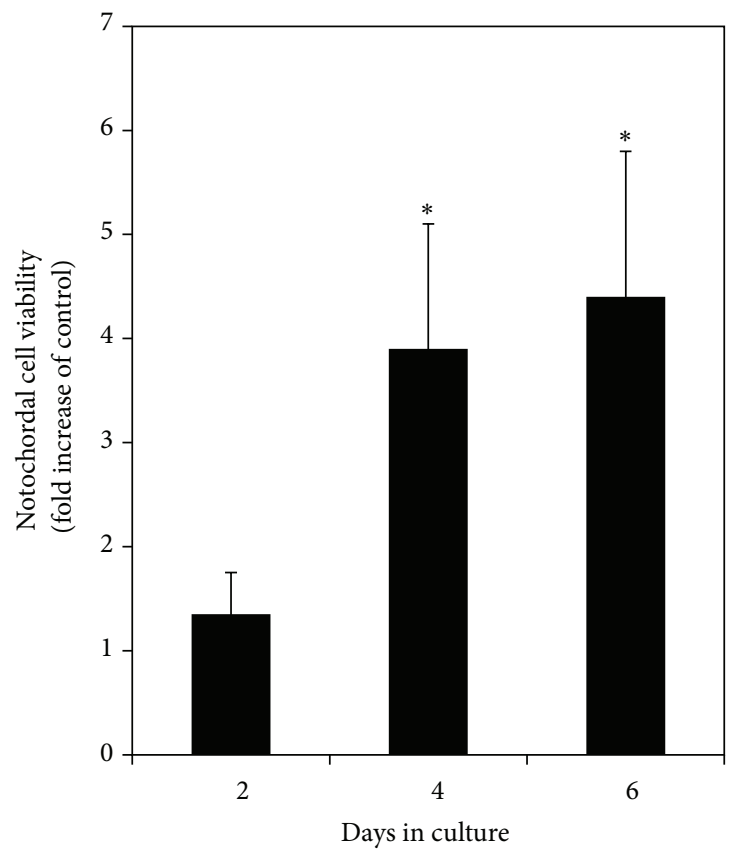

(g)

FIGURE 1: Photomicrographs of a chick embryo at stage 8 (a), an isolated notochord (b), and the somites (c) from the chick embryo. Encapsulated notochord in alginate bead was cultured for 2 (d), 4 (e), and 6 days (f). The survival rate of the notochordal cells was quantified by MTT assay during different days in culture and presented as fold increase of control after normalizing with the same cells on day 0 (Control group upon isolation) $\left({ }^{*} P<0.05\right)($ bar $=50 \mu \mathrm{m})$. 
TABLE 1: Primer sequences, annealing temperature (AT), the length of amplified products (bp), and number of cycles for different genes.

\begin{tabular}{|c|c|c|c|c|}
\hline Gene & Primer Sequence $\left(5^{\prime} \rightarrow 3^{\prime}\right)$ & $\mathrm{AT}\left({ }^{\circ} \mathrm{C}\right)$ & Length (bp) & Cycle \\
\hline GAPDH & $\begin{array}{l}\text { F: AGTCATCCCTGAGCTGAATG } \\
\text { R: AGGATCAAGTCCACAACACG }\end{array}$ & 50 & 330 & 28 \\
\hline Pax3 & $\begin{array}{l}\text { F: GCGTCGCAGCAGGACAACCT } \\
\text { R: GCGCTGGGTGGAAACCCTCC }\end{array}$ & 61.5 & 218 & 32 \\
\hline$B M P 4$ & $\begin{array}{c}\text { F: GACCGGCAGGAAGAAAGTCG } \\
\text { R: GCACGCTGCTGCTGAGGTTGAAG }\end{array}$ & 59 & 352 & 32 \\
\hline Bcl2 & $\begin{array}{l}\text { F: TACCTGCTTACACTTAGGAA } \\
\text { R: ATGACTATGATGCGATGGCA }\end{array}$ & 54.2 & 330 & 32 \\
\hline Caspase 2 & $\begin{array}{c}\text { F: GTGGATTCCTGTATTGTAGC } \\
\text { R: ATCCACGCTTGGTGTTGC }\end{array}$ & 49.2 & 302 & 35 \\
\hline Paxl & $\begin{array}{l}\text { F: GCTGGGTGGTGTCTTCGTGAAC } \\
\text { R: ACTGGTAAAGGGGGTTGTAGGG }\end{array}$ & 55 & 451 & 35 \\
\hline MyoD & $\begin{array}{c}\text { F: ACTACACGGAATCACCAAATGACC } \\
\text { R: AAGGAATCTGGGCTCCACTGTC }\end{array}$ & 55 & 200 & 35 \\
\hline
\end{tabular}

\section{Results}

3.1. Survival Assay for Encapsulated Notochord. To prevent notochord from mixing with the somites, it was encapsulated in alginate beads and studied 2, 4, and 6 days after culturing. To assess survival of notochordal cells in culture condition, MTT test was also done. Microscopic observations showed that the notochord became thick and rolled on its axis (Figures $1(\mathrm{~d})-1(\mathrm{f})$ ) and the survival rate of its cells increased from $1.35 \pm 0.4$ folds on day 2 to $3.9 \pm 1.2$ and $4.4 \pm 1.4$ times on 4 and 6 days after culturing, respectively (Figure $1(\mathrm{~g}), P<$ $0.05)$.

3.2. Morphology of Somitic Cells. The somites were cultured with (Som + Not group) and without notochord (Som group) for 2-10 days. After $24 \mathrm{~h}$, isolated somites started to spread onto the culture dish (Figures 2(a) and 2(b)) and after 2 days many somitic cells expanded (Figures 2(c) and 2(d)). Our results also indicated that morphology of somitic cell in Som + Not group changed to a slender shape accompanying with short and thin processes (Figures 2(e) and $2(\mathrm{~g})$ ). However, the same morphology in a few somitic cells of Som group was seen after 6-day culture (Figure 2(f)). Finally, many somitic cells in both groups underwent death and apoptotic bodies appeared on day 10 after culturing (Figure 2(h)).

3.3. Survival of Somites Cocultured with Notochord. To evaluate in vitro somitic cell survival, the somites were cocultured with alginate-encapsulated notochord. After 2 days, $59 \pm$ $12.8 \%$ of somitic cells were alive in the presence of notochord (Som + Not) compared to $51.3 \pm 6.9 \%$ of the cells in Som group $(P>0.05$, Figure 3$)$. After 4 and 6 days coculture with notochord, $74.4 \pm 16.4 \%$ and $89.7 \pm 17.9 \%$ of the somitic cells in Som + Not group significantly appeared to be alive compared to $28.2 \pm 5.1 \%$ and $53.8 \pm 10.3 \%$ of the cells in Som group, respectively $(P<0.05$, Figure 3$)$. Ten days after culturing, the somitic cells started to die and only $38.5 \pm 7.7 \%$ of them were alive in Som + Not group in comparison with the cells in Som group $(17.9 \pm 5.1 \%, P<0.05$, Figure 3$)$.

3.4. Analysis of Gene Expression. RT-PCR was used for analyzing genes' expression involved in apoptosis pathway and those have a role in somitic differentiation into sclerotome and dermomyotome. Since 6 days coculturing of somites with notochord indicated better results, we used this coculturing time in the rest of experiments. Semiquantitative RT-PCR analysis confirmed our morphological results and showed somewhat upregulation of BMP4 expression in somitic cells in Som + Not group. Bcl 2 as a marker for survival cells was also upregulated in Som + Not group. In contrast, Caspase2 expression was significantly upregulated in Som group on day 6 compared to the cells in Som group on day 0 (Control group) and Som + Not group on day $6(P<0.05)$ (Figure 4$)$. As stated, six days after coculturing with notochord, morphology of the somitic cells group changed to slender shape (Figure 2(e)). These cells also expressed Paxl, a sclerotomal cell marker and downregulated myotomal cell marker, $M y o D$ and Pax3, an early somitic cell marker compared to cells in Som (day 0) group and the cells of Som group (day 6) $(P<0.05)$ (Figure 4). Taken together, these findings showed diminishes of apoptosis in somitic cells and their direction to sclerotome differentiation following coculture with notochord.

3.5. Caspase-2 Activity in Somites. Spectrophotometry assay was used to evaluate Caspase-2 enzyme activity in somitic cells. Our results indicated $1.78 \pm 0.18$-fold increase activity of Caspase-2 in Som group, but it significantly decreased to $1.27 \pm 0.16$-fold increase in Som + Not group $(P<0.05$, Figure 5).

\section{Discussion}

Our results present another evidence for survival effect of the notochord on somites by using alginate-based coculture system, a strategy that provides an appropriate in vitro study method for cell-cell interactions without direct mixing 


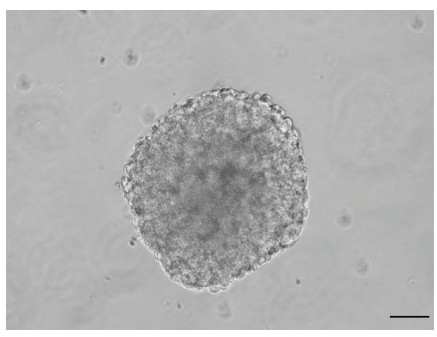

(a)

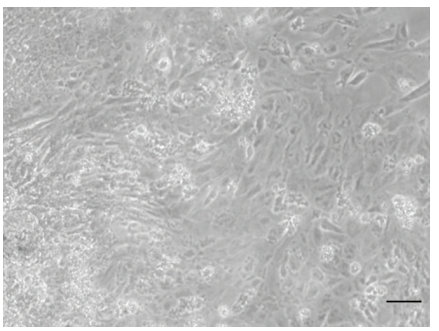

(d)

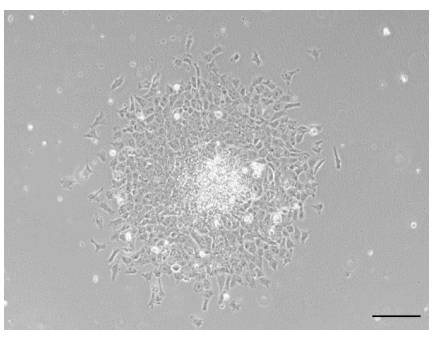

(b)

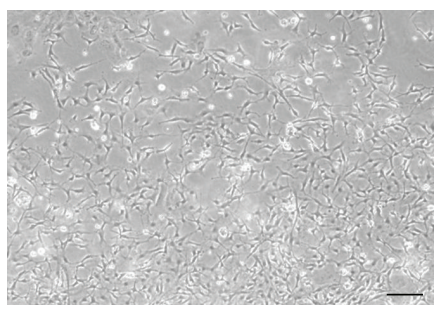

(e)

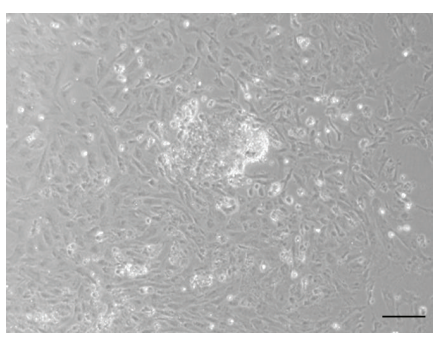

(c)

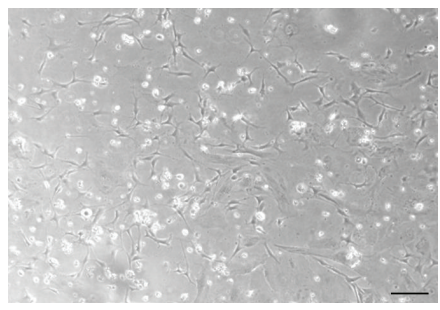

(f)



(g)

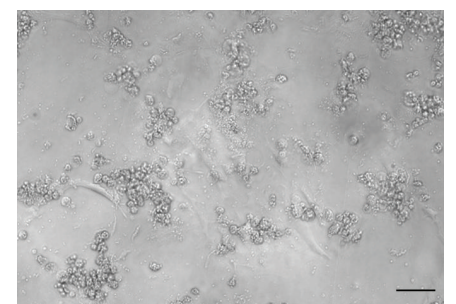

(h)

FIgURE 2: Photomicrographs of the somite upon isolation from chick embryo (a) and twenty-four hours after plating (b). The somitic cells were grown with notochord (Som + Not group) ((c) and (e)), and without it (Som group) ((d) and (f)) for 2 and 6 days, respectively. These cells indicated morphology of mesenchymal-like cells with thin and short processes, especially in Som + Not group (g). After 10 days, a large variety of somitic cells in both groups showed apoptosis $(\mathrm{h})(\mathrm{bar}=50 \mu \mathrm{m})$.

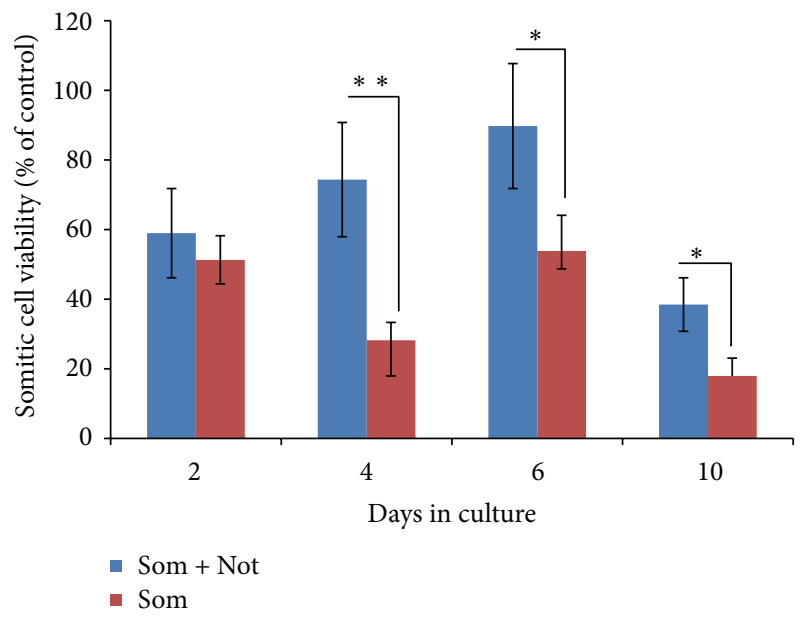

FIgURE 3: Percentage of viable somitic cells normalized with the same cells on day 0 (Control group upon isolation) was quantified by MTT test in Som + Not and Som groups during different days in culture $\left({ }^{*} P<0.05,{ }^{* *} P<0.02\right)$.

of notochord with somites. Alginic acid is a widely used component for cell encapsulation in which entrapped cells are immobilized but allowed to release their secretion into medium due to porosity in alginate bead [21-24]. Previous studies revealed that alginate can promote proliferation or apoptosis in encapsulated cells but has not effect on plated cells when added to culture media without entrapped cells. Moreover, another investigation showed that the notochord cocultured with embryonic stem cells began to proliferate enrolled in alginate bead after four-day encapsulation [19, $20,22,25]$. Since in coculture system, the culture condition should support both tissues or cell types, we studied viability of notochordal cells in culture condition. Our findings showed the encapsulated notochordal cells after 6 days culture had about 4.4 times more survival rate than the same cells on day 0 . These results clearly indicate that the alginate doesn't have any apoptotic effect on notochordal cells but in contrast, it allows the notochordal cells to be alive and possibly proliferate in culture condition.

Several studies have shown that the presence of tissues surrounding the somites is required for somitic cells maintenance and patterning in the mouse and chick embryos and in the absence of midline structures of the embryo, the somite-derived cells undergo apoptosis. However, the somites appeared to have a greater size and significantly enhanced viability when the neural tube was located adjacent to the 


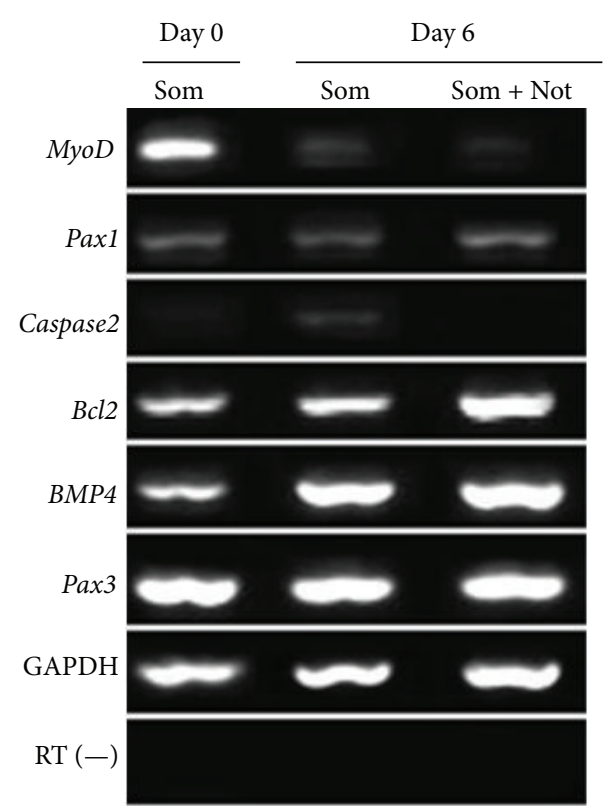

(a)

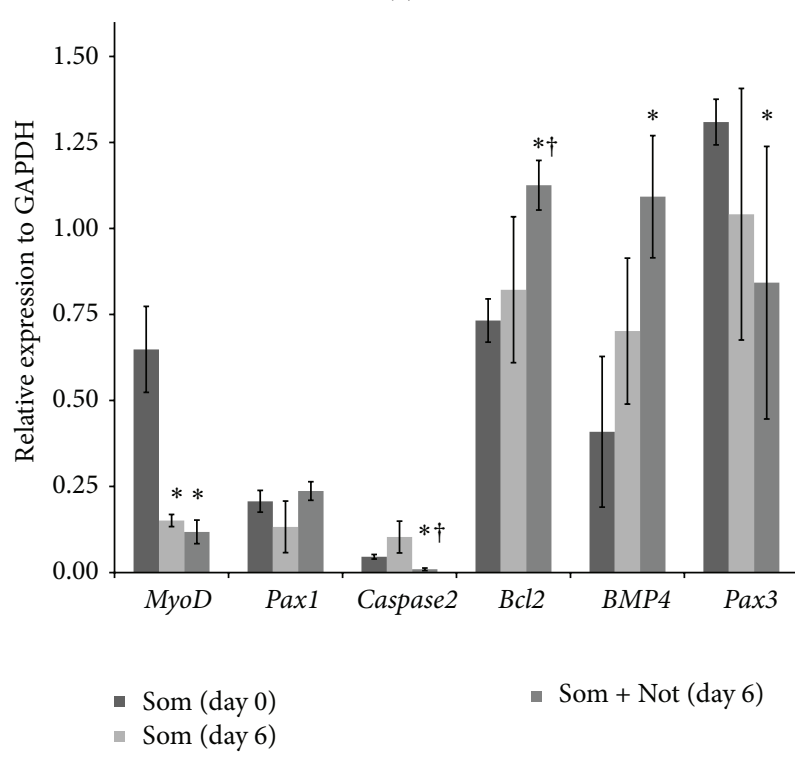

(b)

FIGURE 4: RT-PCR analysis for somitic cells in somite groups on day 0 and 6 and somite cocultured with notochord (Som + Not) group six days after culturing (a). Semiquantitative analysis clearly showed that expression of Paxl, Bcl2, and BMP4 was upregulated in somitic cells cocultured with notochord but MyoD, Caspase-2, and Pax3 expressions were downregulated compared to the cells in Som (day 0$)\left({ }^{*} P<0.05\right)$ and Som (day 6$)$ groups $\left({ }^{\dagger} P<0.05\right)($ b).

somites [9, 26]. Moreover, it has been revealed that Shh secreted from the midline structures acts as a survival and proliferative factor for somitic cells and mimics the effect of notochord on them to differentiate into sclerotome. This signaling molecule also maintains myotomal and dermomyotomal cell survival, since Shh mutation in mouse embryo resulted in impairment of the maintenance of cell survival in the sclerotome $[9,27,28]$. In our study, the encapsulated

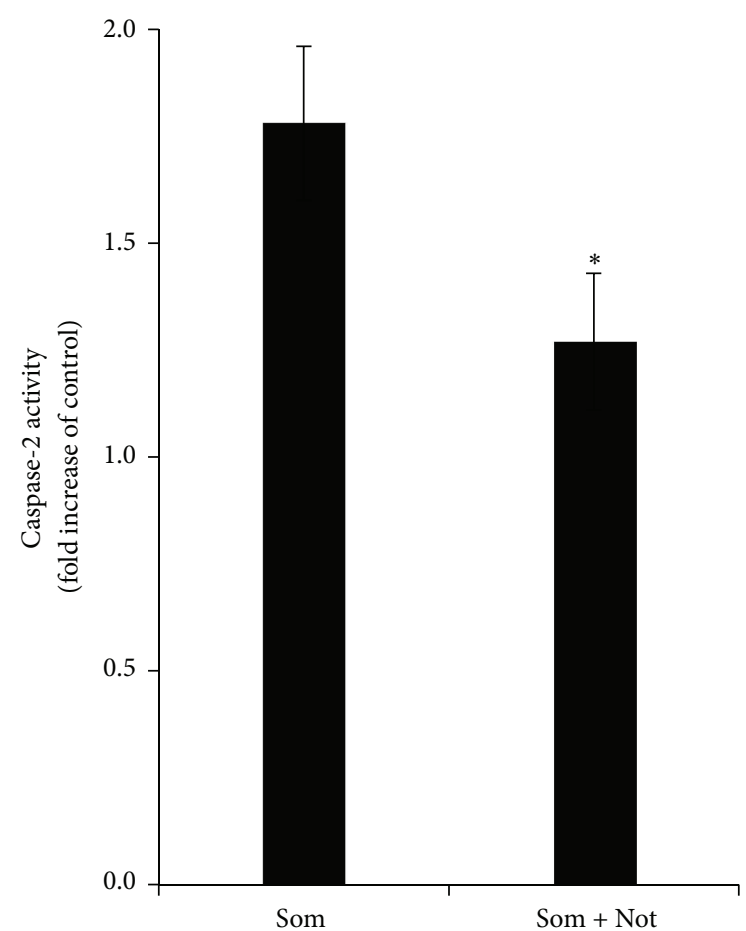

FIGURE 5: Caspase-2 enzyme in somitic cells showed about 1.8-fold increase activity in somite group (Som) after 6 days in culture. In Som + Not group, Caspase- 2 activity in somitic cells significantly decreased $\left({ }^{*} P<0.05\right)$.

notochord increased somitic cells viability, so that, 6 days after coculturing, about $90 \%$ of somitic cells in Som + Not group significantly were alive compared to $50 \%$ in Som group. It is possible that the somitic cells are proliferated in presence of the notochord. However, after 10 days, the somitic cells underwent apoptosis in both groups. The presence of exogenous survival signals such as Shh may be needed in culture medium, since after 10 days the notochordal cells started to die and they could not support somitic cell survival.

Previous work indicated that the somites isolated from axial structures of the early embryo undergo programmed cell death and Caspase-2, as an upstream initiator enzyme involved in developing tissues apoptosis such as somite, is overexpressed, while $\mathrm{Bcl}-2$ expression, as an antiapoptotic marker, is diminished [10]. Our results are consistent with recent findings, since 6 days after coculturing, gene expression profile clearly showed high $\mathrm{Bcl}-2$ and low Caspase-2 expression in somitic cells in Som + Not group compared to the cells in Som group in which the rate of apoptotic somitic cells was high. These results were also confirmed by Caspase2 enzyme activity assay by which the activity of Caspase- 2 in somitic cells was significantly lower in Som + Not group than the cells in Som group.

It has been shown that the fate of somitic cells is controlled by extrinsic factors emanating from the surrounding tissues including axial structures [26, 29, 30]. Based on misexpression experiments in chick embryo, Pax3 transcription factor is expressed in the early developing somites and then it is restricted to dermomyotome. Mutation in Pax3 
results in apoptosis in presomitic mesoderm and developing somites [31]. In addition, BMP4 expression in lateral plate mesoderm leads to differentiation in lateral side of the somites, but a BMP antagonist, noggin, expressed in medial side of somite, broadly expands myogenic lineage regulator, $M y o D$ and Myf5 expression in epaxial muscle precursor cells $[32,33]$. Expression of these myogenic regulator genes in somites will be upregulated by combinatorial signaling factors from notochord and neural tube/roof plate and localized expression of Shh also activates MyoD and Paxl expression but inhibits Pax3 expression [27, 34, 35]. These findings are in contrast with using notochord alone that is not sufficient for $M y o D$ and $M y f-5$ expression in somite [26]. Our RT-PCR analysis was consistent with these studies and confirmed that Pax3 is expressed in somite and that the notochord slightly decreased Pax3 expression in somitic cells but increased Pax1 expression after 6-day coculturing. These results also showed that the cultured somitic cells in Som + Not group morphologically changed to mesenchymal-like cells with short and thin process represented differentiation into Paxl expressing sclerotomal cells, but MyoD expression was rigorously downregulated compared to the cells in Som groups on day 0 and 6 . The information presented here supports the idea that the notochord enhances the viability of somitic cell in in vitro through decreasing the apoptosis and induces somitic cell differentiation.

\section{Conclusions}

Taken together, this study clearly shows that the presence of the notochord cocultured with somite enhances in vitro somitic cell survival and inhibits apoptosis through Caspase2 downregulation and $\mathrm{Bcl}-2$ upregulation and likely promotes in vitro differentiation of somitic cells to sclerotomal cells by Paxl overexpression and $M y o D$ downregulation.

\section{Acknowledgment}

This study was funded by a Grant provided from Research Council for Ardabil University of Medical Sciences (Iran).

\section{References}

[1] B. Christ and C. P. Ordahl, "Early stages of chick somite development," Anatomy and Embryology, vol. 191, no. 5, pp. 381396, 1995.

[2] B. Brand-Saberi, J. Wilting, C. Ebensperger, and B. Christ, "The formation of somite compartments in the avian embryo," International Journal of Developmental Biology, vol. 40, no. 1, pp. 411-420, 1996.

[3] C. D. Stern and D. Vasiliauskas, "Clocked gene expression in somite formation," BioEssays, vol. 20, no. 7, pp. 528-531, 1998.

[4] M. J. McGrew and O. Pourquié, "Somitogenesis: segmenting a vertebrate," Current Opinion in Genetics and Development, vol. 8, no. 4, pp. 487-493, 1998.

[5] J. S. Eisen, "Patterning motoneurons in the vertebrate nervous system," Trends in Neurosciences, vol. 22, no. 7, pp. 321-326, 1999.
[6] A. Poh, A. Karunaratne, G. Kolle et al., "Patterning of the vertebrate ventral spinal cord," International Journal of Developmental Biology, vol. 46, no. 4, pp. 597-608, 2002.

[7] R. Shirasaki and S. L. Pfaff, "Transcriptional codes and the control of neuronal identity," Annual Review of Neuroscience, vol. 25, pp. 251-281, 2002.

[8] L. Wilson and M. Maden, "The mechanisms of dorsoventral patterning in the vertebrate neural tube," Developmental Biology, vol. 282, no. 1, pp. 1-13, 2005.

[9] G. M. Cann, J. W. Lee, and F. E. Stockdale, "Sonic hedgehog enhances somite cell viability and formation of primary slow muscle fibers in avian segmented mesoderm," Anatomy and Embryology, vol. 200, no. 3, pp. 239-252, 1999.

[10] E. J. Sanders and E. Parker, "Ablation of axial structures activates apoptotic pathways in somite cells of the chick embryo," Anatomy and Embryology, vol. 204, no. 5, pp. 389-398, 2001.

[11] R. A. Schwartzman and J. A. Cidlowski, "Apoptosis: the biochemistry and molecular biology of programmed cell death," Endocrine Reviews, vol. 14, no. 2, pp. 133-151, 1993.

[12] A. Gewies, "Introduction to apoptosis," ApoReview, pp. 1-26, 2003.

[13] J. C. Reed, "Bcl-2 and the regulation of programmed cell death," Journal of Cell Biology, vol. 124, no. 1-2, pp. 1-6, 1994.

[14] R. M. Kluck, E. Bossy-Wetzel, D. R. Green, and D. D. Newmeyer, "The release of cytochrome c from mitochondria: a primary site for Bcl- 2 regulation of apoptosis," Science, vol. 275, no. 5303, pp. 1132-1136, 1997.

[15] D. Wallach, E. E. Varfolomeev, N. L. Malinin, Y. V. Goltsev, A. V. Kovalenko, and M. P. Boldin, "Tumor necrosis factor receptor and Fas signaling mechanisms," Annual Review of Immunology, vol. 17, pp. 331-367, 1999.

[16] J. C. Reed, "Warner-Lambert/Parke Davis award lecture: mechanisms of apoptosis," American Journal of Pathology, vol. 157, no. 5, pp. 1415-1430, 2000.

[17] H. Salehi, K. Karbalaie, S. Razavi et al., "Neuronal induction and regional identity by co-culture of adherent human embryonic stem cells with chicken notochords and somites," International Journal of Developmental Biology, vol. 55, no. 3, pp. 321-326, 2011.

[18] H. Salehi, K. Karbalaie, A. Salamian et al., "Differentiation of human ES cell-derived neural progenitors to neuronal cells with regional specific identity by co-culturing of notochord and somite," Stem Cell Research, vol. 8, no. 1, pp. 120-133, 2012.

[19] M. Sagha, K. Karbalaie, S. Tanhaee et al., "Neural induction in mouse embryonic stem cells by co-culturing with chicken somites," Stem Cells and Development, vol. 18, no. 9, pp. 13511359, 2009.

[20] M. Anjomshoa, K. Karbalaie, M. Mardani et al., "Generation of motor neurons by coculture of retinoic acid-pretreated embryonic stem cells with chicken notochords," Stem Cells and Development, vol. 18, no. 2, pp. 259-267, 2009.

[21] O. Smidsrod and G. Skjak-Braek, "Alginate as immobilization matrix for cells," Trends in Biotechnology, vol. 8, no. 3, pp. 71-78, 1990.

[22] H. J. Kong, M. K. Smith, and D. J. Mooney, "Designing alginate hydrogels to maintain viability of immobilized cells," Biomaterials, vol. 24, no. 22, pp. 4023-4029, 2003.

[23] S. Gerecht-Nir, S. Cohen, A. Ziskind, and J. Itskovitz-Eldor, "Three-dimensional porous alginate scaffolds provide a conducive environment for generation of well-vascularized embryoid bodies from human embryonic stem cells," Biotechnology and Bioengineering, vol. 88, no. 3, pp. 313-320, 2004. 
[24] L. N. Novikova, A. Mosahebi, M. Wiberg, G. Terenghi, J.-O. Kellerth, and L. N. Novikov, "Alginate hydrogel and matrigel as potential cell carriers for neurotransplantation," Journal of Biomedical Materials Research - Part A, vol. 77, no. 2, pp. 242252, 2006.

[25] R. Freshney, Culture of Animal Cells, a Manual Basic Technology, John Wiley \& Sons, New York, NY, USA, 4th edition, 2000.

[26] A. E. Munsterberg and A. B. Lassar, "Combinatorial signals from the neural tube, floor plate and notochord induce myogenic bHLH gene expression in the somite," Development, vol. 121, no. 3, pp. 651-660, 1995.

[27] C. Marcelle, S. Ahlgren, and M. Bronner-Fraser, "In vivo regulation of somite differentiation and proliferation by Sonic Hedgehog," Developmental Biology, vol. 214, no. 2, pp. 277-287, 1999.

[28] A.-G. Borycki, B. Brunk, S. Tajbakhsh, M. Buckingham, C. Chiang, and C. P. Emerson Jr., "Sonic hedgehog controls epaxial muscle determination through Myf5 activation," Development, vol. 126, no. 18, pp. 4053-4063, 1999.

[29] F. E. Stockdale, Nikovits WJr, and B. Christ, "Molecular and cellular biology of avian somite development," Developmental Dynamics, vol. 219, no. 3, pp. 304-321, 2000.

[30] B. Christ and M. Scaal, "Formation and differentiation of avian somite derivatives," Advances in Experimental Medicine and Biology, vol. 638, pp. 1-41, 2008.

[31] A.-G. Borycki, J. Li, F. Jin, C. P. Emerson Jr., and J. A. Epstein, "Pax3 functions in cell survival and in pax7 regulation," Development, vol. 126, no. 8, pp. 1665-1674, 1999.

[32] E. Hirsinger, C. Jouve, P. Malapert, and O. Pourquié, "Role of growth factors in shaping the developing somite," Molecular and Cellular Endocrinology, vol. 140, no. 1-2, pp. 83-87, 1998.

[33] R. Reshef, M. Maroto, and A. B. Lassar, "Regulation of dorsal somitic cell fates: BMPs and Noggin control the timing and pattern of myogenic regulator expression," Genes and Development, vol. 12, no. 3, pp. 290-303, 1998.

[34] A.-G. Borycki, L. Mendham, and C. P. Emerson Jr., "Control of somite patterning by Sonic hedgehog and its downstream signal response genes," Development, vol. 125, no. 4, pp. 777-790, 1998.

[35] M.-A. Teillet, Y. Watanabe, P. Jeffs, D. Duprez, F. Lapointe, and N. M. Le Douarin, "Sonic hedgehog is required for survival of both myogenic and chondrogenic somitic lineages," Development, vol. 125, no. 11, pp. 2019-2030, 1998. 

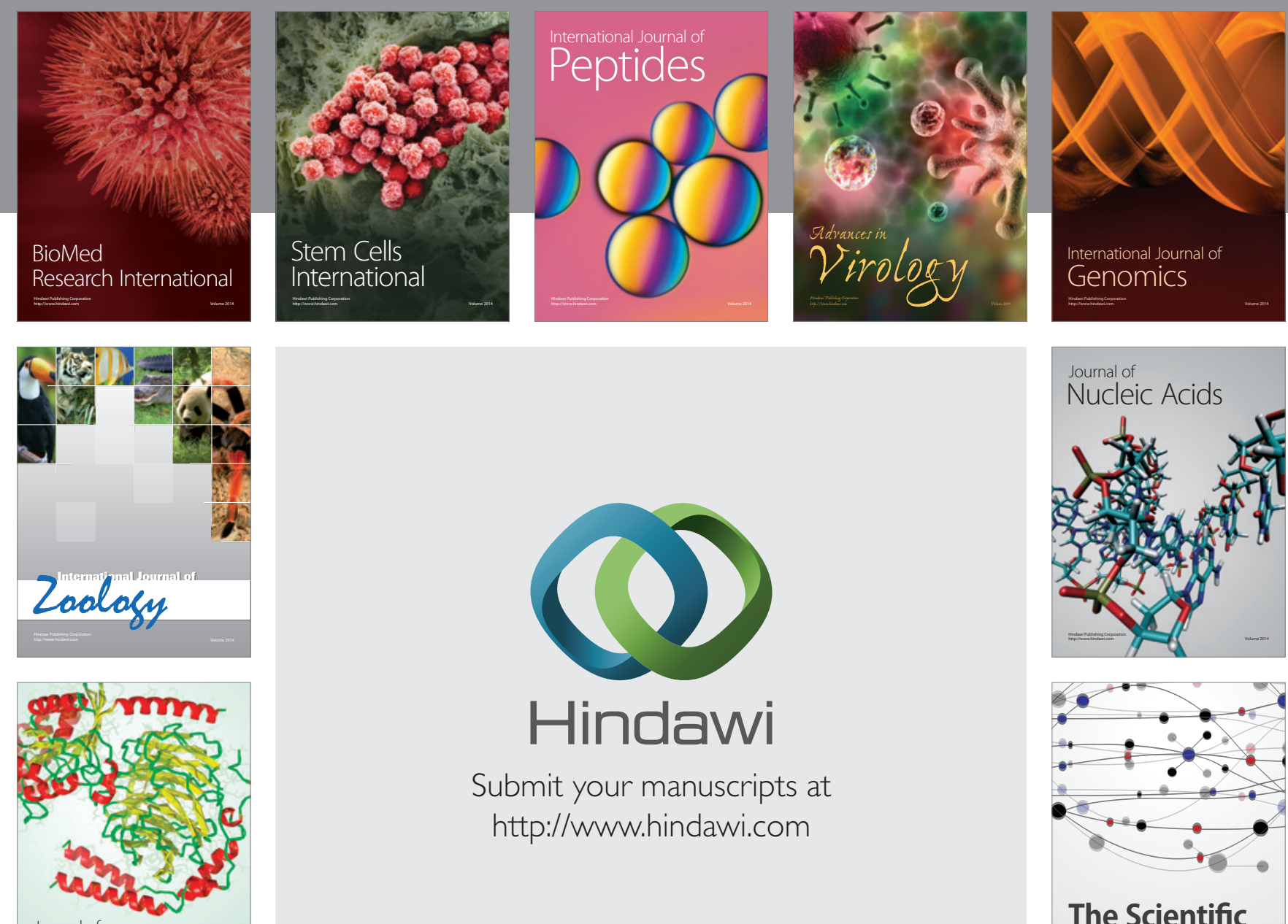

Submit your manuscripts at

http://www.hindawi.com

Journal of
Signal Transduction
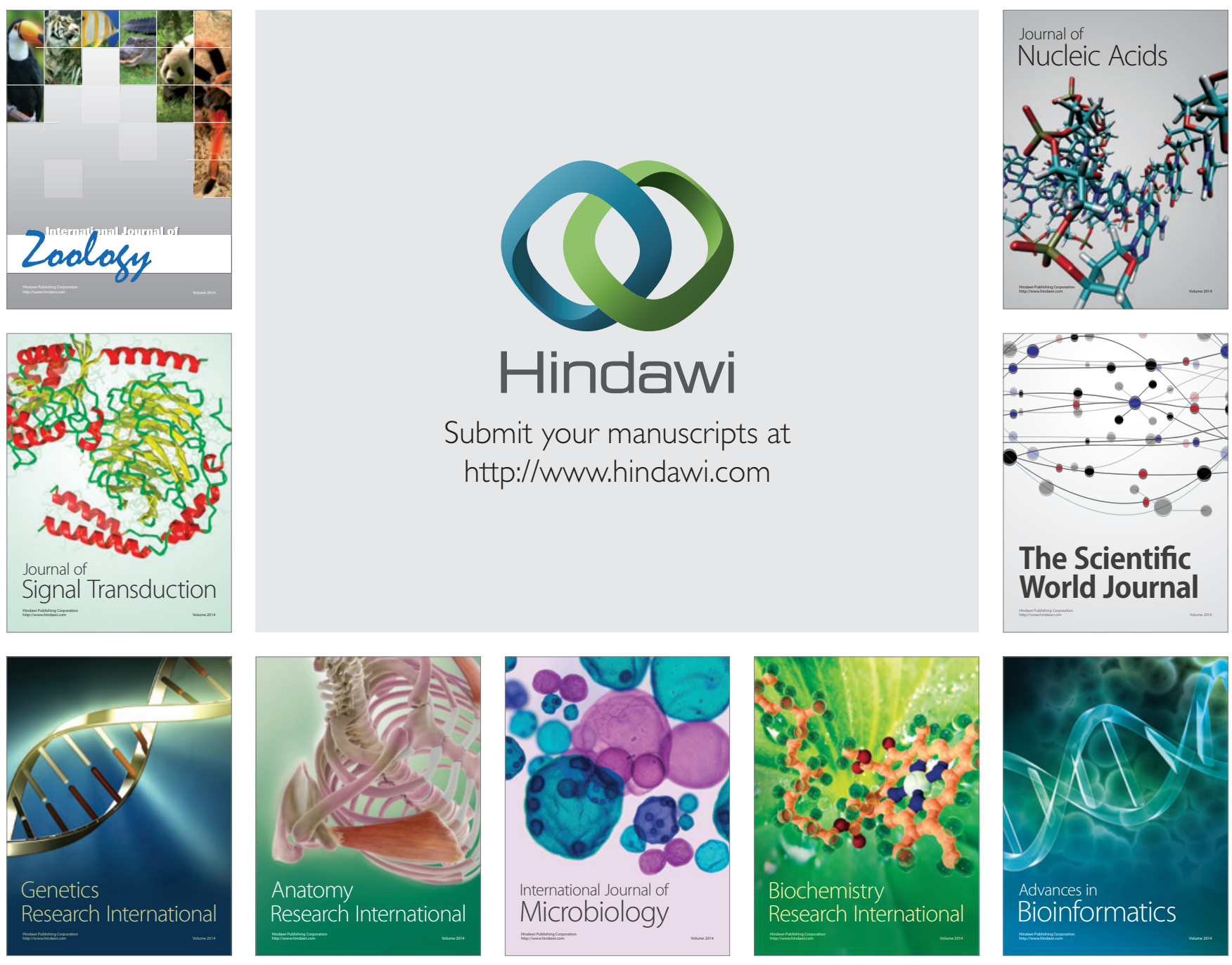

The Scientific World Journal
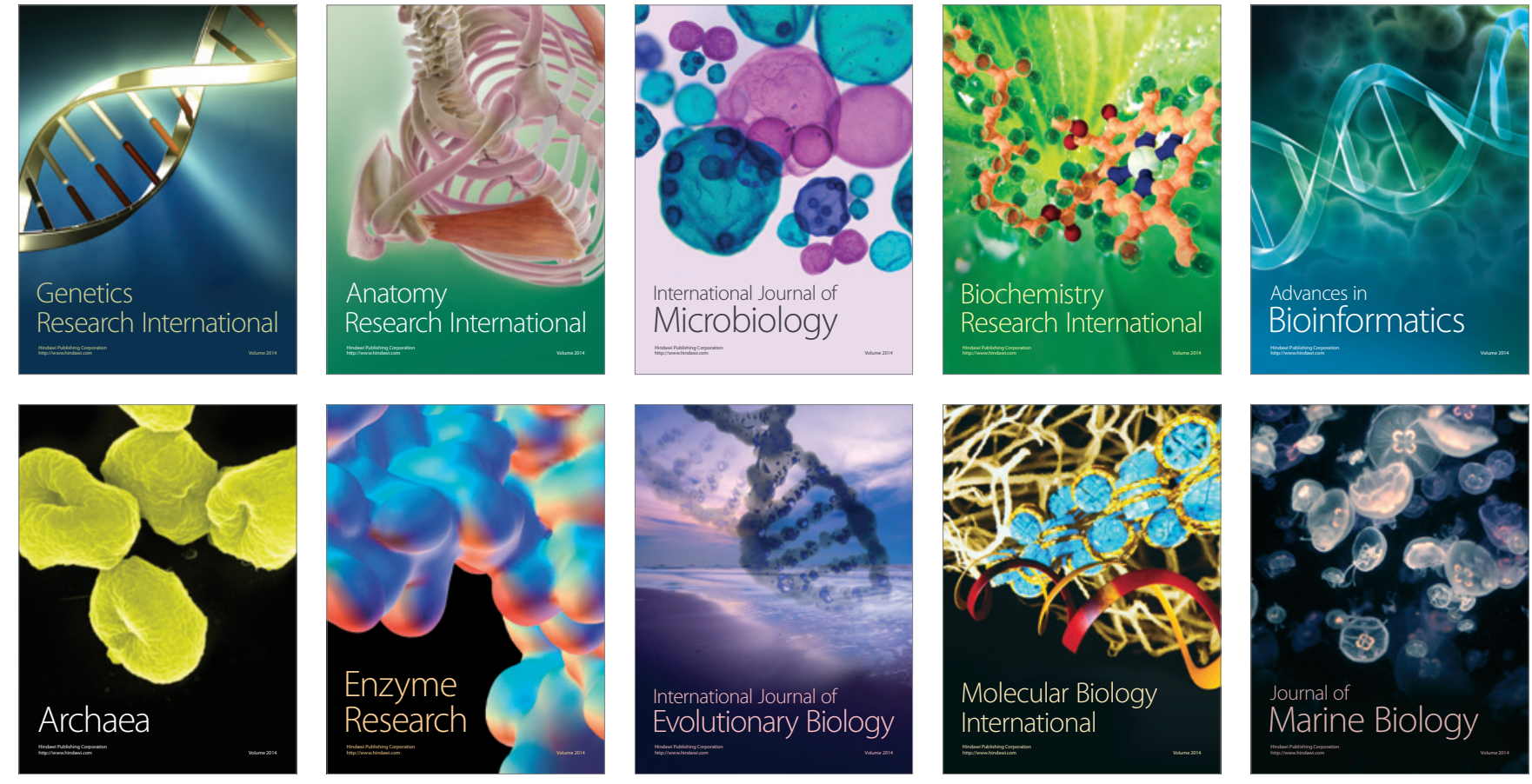